\title{
Amiloride Inhibits Mammalian Renal Kallikrein and a Kallikrein-like Enzyme from Toad Bladder and Skin
}

\author{
Harry S. Margolius and Julie ChaO, Departments of Pharmacology and \\ Medicine, Medical University of South Carolina, Charleston, South \\ Carolina 29403
}

A B S T R A C T Renal kallikrein is localized in luminal plasma membranes of the mammalian distal nephron and gains access to urine from this site. Its activity is regulated, in part, by aldosterone. These facts led us to study the effects of amiloride, a drug known to inhibit sodium reabsorption and potassium secretion at this site, on kallikrein activity. Amiloride inhibited the esterolytic activity of purified rat or human urinary kallikrein or of rat renal cortical cells upon a synthetic substrate $\left(\mathrm{ID}_{50}=0.12-0.23 \mathrm{mM}\right)$. Kinetic analyses showed that the enzyme inhibition was noncompetitive and reversible in nature. The kinin-generating activity of kallikrein acting upon kininogen substrates was also inhibited by amiloride, as measured by bioassay in the rat uterus or guinea pig ileum or by radioimmunoassay of liberated kinins $\left(\mathrm{ID}_{50}=85\right.$ $\mu \mathrm{M})$. No other diuretic drug tested inhibited kallikrein activity, except triamterene, which did so, weakly. In addition, kallikrein-like enzyme activity was discovered in the urinary bladder or skin of Bufo marinus toads and this activity was also inhibited by amiloride. The localization of the enzyme and its inhibition by this drug suggest that further study of relationships amongst the glandular kallikrein-kinin system and renal ion and water transport is warranted.

\section{INTRODUCTION}

Urinary and renal kallikreins (E.C. 3.4.21.8) are serine proteinases which act upon kininogen substrates to liberate kallidin (lysyl-bradykinin), a decapeptide with a broad spectrum of biological activity includ-

This work was presented in part at the 7th International Congress of Pharmacology, Paris, July (Abstr. 414) and the International Symposium on Kinins, Tokyo, November 1978 (Abstr. II-3) and has previously been published in part in abstract form: 1978. Clin. Res. 26: 63A.

Dr. Margolius is a Burroughs-Wellcome Scholar in Clinical Pharmacology. Dr. Chao is a Research Career Development Awardee of the National Heart, Lung, and Blood Institute.

Received for publication 24 September 1.979 and in revised form 1.5 February 1.980. ing effects upon sodium and water transport across membranes $(1,2)$. In humans and rats, sodium-retaining steroids or maneuvers which increase aldosterone activity, such as reduced dietary sodium or increased dietary potassium increase renal and urinary kallikrein activity; whereas spironolactone reduces it (3-9). Kallikrein excretion is elevated in primary aldosteronism or Bartter's syndrome (10-13). In the rat kidney, kallikrein is localized at the apical portions of cells of the distal nephron $(14,15)$ and is membrane bound (16). Its active sites face the exterior of renal cortical cells in suspension (17). These findings led us to ask whether kallikrein's enzymatic activities would be affected by amiloride, an $\mathrm{N}$-amidino pyrazine carboxamide known to block entry of sodium ions into a transport mechanism by an action at the distal nephron luminal surface (18). The results of these studies show that all of the established enzymatic properties of kallikrein are inhibited by this drug. In addition, amiloride inhibited a new kallikrein-like enzyme activity found in Bufo marinus urinary bladder and skin.

\section{METHODS}

\section{Materials}

The following materials were obtained from commercial sources: Sephadex G-25 (superfine) (Pharmacia Fine Chemicals, Div. of Pharmacia Inc., Piscataway, N. J.); $\alpha-N$-tosyl-Larginine methyl ester (Tos-Arg-OMe)' (Schwarz/Mann Div., Becton, Dickinson \& Co., Orangeburg, N. Y.); Tos-Arg$0\left[{ }^{3} \mathrm{H}\right] \mathrm{Me}$ (sp act $\sim 200 \mathrm{Ci} / \mathrm{mol}$ ) (Biochemical and Nuclear Corp., Burbank, Calif.); aprotinin (identical to Kunitz basic pancreatic trypsin inhibitor), phenylmethylsulfonyl fluoride, trypsin (from bovine pancreas, type IV, twice crystallized), 5,5'-dithiobis(2-nitrobenzoic acid), benzamidine (Sigma Chemical Co., St. Louis, Mo.); Nitex (Tetko Inc., Elmsford, N. Y.); sodium deoxycholate, polyethylene glycol (6,000 flake) (Fisher Scientific Co., Pittsburgh, Pa.); trypsin inhibitors from

\footnotetext{
${ }^{1}$ Abbreviations used in this paper: EU, esterase unit; IRT$36, \alpha, \alpha^{\prime}, \alpha^{\prime \prime}$-Tris[14-amidino-2-bromophenoxy]mesitylene; IRT-63, $\alpha, \alpha^{\prime}, \alpha^{\prime \prime}$-Tris[3-amidino-phenoxy]mesitylene; Tos-ArgOMe, $\alpha$-N-tosyl-L-arginine methyl ester.
} 
soybean, ovomucoid, lima bean, and carboxypeptidase B (Worthington Biochemical Corp., Freehold, N. J.); synthetic bradykinin and tyrosyl-bradykinin (Peptide Institute-Protein Research Foundation, Osaka, Japan); ouabain (CalbiochemBehring Corp., American Hoechst Corp., San Diego, Calif.).

The following drugs and chemicals were gifts: amiloride (a gift of Dr. Edward J. Cragoe, Jr.), hydrochlorothiazide, ethacrynic acid (Merck Institute for Therapeutic Research, West Point, Pa.); furosemide (Hoechst-Raussel Pharmaceuticals, Inc., Somerville, N. J.); triamterene (SK. \& F Co., Carolina, P. R.); spironolactone (Searle \& Co., San Juan, P. R). Pentamidine and the tris-amidine derivatives: $\alpha, \alpha^{\prime}, \alpha^{\prime \prime}$-Tris[14-amidino-2-bromophenoxy]mesitylene (IRT-36) and $\alpha, \alpha^{\prime}, \alpha^{\prime \prime}$-tris[3-amidino-phenoxy]mesitylene (IRT-63); were gifts from Dr. J. D. Geratz and Dr. R. R. Tidwell, University of North Carolina. SQ20881 was a gift from Dr. Z. Horowitz of the Squibb Institute for Medical Research, New Brunswick, N. J. Thiobenzyl benzyloxycarbonyl-L-lysinate was a gift from Dr. C. Kettner and Dr. E. Shaw, Brookhaven National Laboratory, Upton, N. Y. Partially purified human urinary kallikrein was a gift from Dr. J. V. Pierce, National Institutes of Health, and purified bovine low molecular weight kininogen $\left(17.4 \text { U/A } \mathbf{A}_{\mathbf{2 8 0}}\right)^{2}$ was supplied by Dr. H. Kato of the Protein Research Institute, University of Osaka, Osaka, Japan.

\section{Rat urinary kallikrein purification and assays}

Rat urinary kallikrein B was purified to homogeneity as described previously (19) and its purity was determined by polyacrylamide slab gel electrophoresis and isoelectric focusing. The molecular weight of this enzyme is 35,500 daltons and its isoelectric point is 4.26 . Its activity was measured with four separate assay systems as described below.

\section{Radiochemical Tos-Arg-OMe esterase assay}

A modification (3) of the method of Beaven et al. (20) was used routinely to determine Tos-Arg-OMe esterase activity, a measure of kallikrein-like enzyme activity. The assay was carried out in 1.5-ml polypropylene tubes to which $0.03 \mathrm{ml}$ of $0.2 \mathrm{M}$ Tris- $\mathrm{HCl}(\mathrm{pH} 8$ ) (assay buffer) and $0.02 \mathrm{ml}$ of the enzyme solution with or without drug were added, mixed, and allowed to stand for $30 \mathrm{~min}$ at $25^{\circ} \mathrm{C}$. Then $0.01 \mathrm{ml}$ Tos-Arg$\mathrm{O}\left[{ }^{3} \mathrm{H}\right] \mathrm{Me}(0.047 \mu \mathrm{Ci}, \sim 200 \mathrm{Ci} / \mathrm{mol})$ was added, mixed, and incubated for $30 \mathrm{~min}$. The $\left[{ }^{3} \mathrm{H}\right]$ methanol released was counted in a Beckman LS-355 liquid scintillation spectrometer (Beckman Instruments, Inc., Fullerton, Calif. [counting efficiency for ${ }^{3} \mathrm{H}, 40 \%$ ]). 1 Tos-Arg-OMe esterase unit (EU) is defined as that amount of enzyme that hydrolyzes $1 \mu \mathrm{mol}$ of Tos-Arg$\mathrm{OMe} / \mathrm{min}$ at $\mathrm{pH} 8$ and $30^{\circ} \mathrm{C}$ using a human urinary kallikrein as a standard in a titrametric. assay (21).

\section{Kininogenase assay}

The method of Shimamoto et al. (22) was used to determine kallikrein's kinin-releasing activity. Generated kinins were measured by a kinin radioimmunoassay (23). The reaction was carried out at $37^{\circ} \mathrm{C} .0 .05 \mathrm{ml}$ of purified rat urinary kallikrein $(0.02 \mathrm{EU} / \mathrm{ml}), 0.05 \mathrm{ml}$ of water or water plus amiloride, and $0.2 \mathrm{ml}$ of $0.1 \mathrm{M}$ phosphate buffer $(\mathrm{pH} 8.5$ ) were mixed and incubated for $30 \mathrm{~min}$ at $37^{\circ} \mathrm{C}$, and then 0.2

${ }^{2} 1 \mathrm{U}$ of kininogen is defined as that amount of low molecular weight kininogen which, after treatment with trypsin, produces contractile activity equivalent to $1 \mu \mathrm{g}$ synthetic bradykinin on the isolated rat uterus. $\mathrm{ml}$ of bovine low molecular weight kininogen $(7.5 \mu \mathrm{g} / \mathrm{ml})$ was added. The reaction tubes were incubated for $20 \mathrm{~min}$ at $37^{\circ} \mathrm{C}$ before stopping the reaction by immersion in boiling water for $10 \mathrm{~min}$. The nonincubated control tubes were immediately placed in boiling water for $10 \mathrm{~min}$. From the nonincubated and incubated tubes, $0.01-\mathrm{ml}$ aliquots were removed and added to $0.19 \mathrm{ml}$ of $0.01 \mathrm{M} \mathrm{Na}$ phosphate, $0.14 \mathrm{M} \mathrm{NaCl}$ ( $\mathrm{pH}$ 7) containing $1 \%$ egg albumin, $0.01 \mathrm{M} \mathrm{Na}_{2}$ EDTA, and $0.003 \mathrm{M}$ phenanthroline (assay buffer) in plastic tubes. Then, $0.1 \mathrm{ml}$ of ${ }^{125}$ I-tyrosyl-bradykinin $(\sim 8,000 \mathrm{cpm})$, prepared monthly as previously described (23), in assay buffer was added and the contents were then mixed. Next, $0.1 \mathrm{ml}$ of rabbit antibradykinin antiserum (1:20,000 dilution) in assay buffer was added to each tube, mixed, and incubated at $4^{\circ} \mathrm{C}$ for $12 \mathrm{~h}$. After incubation, $0.4 \mathrm{ml}$ of ice cold $1 \%$ bovine gamma globulin in phosphate-buffered saline was added to each tube followed by $0.8 \mathrm{ml}$ of ice cold $25 \%$ polyethylene glycol in phosphate-buffered saline. After mixing, the tubes were centrifuged at $3,000 \mathrm{~g}$ for $20 \mathrm{~min}$ at $4^{\circ} \mathrm{C}$, the supernate was carefully aspirated, and then the radioactivity in the unwashed precipitates was counted in a Beckman automatic well-type gamma spectrometer. Values of nonincubated control tubes were subtracted from respective incubated sample values. A seven-point standard curve of synthetic bradykinin assayed in duplicate in concentrations ranging from 2 to $125 \mathrm{pg}$ kinin per tube was used for each assay. In 20 assays, the antibody gave $38.7 \pm 1.7 \%$ (mean $\pm 1 \mathrm{SE}$ ) binding of ${ }^{125}$ I-tyrosyl-bradykinin.

\section{Bioassays}

Guinea pig ileum preparations (24). $0.1-\mathrm{ml}$ aliquots of heated $\left(60^{\circ} \mathrm{C}, 60 \mathrm{~min}\right)$ dog plasma were added to the ileum in a $10-\mathrm{ml}$ isolated tissue bath at $27^{\circ} \mathrm{C}$ and incubated for $1-2$ min. 0.1-ml aliquots of rat urinary kallikrein $(0.1 \mathrm{EU} / \mathrm{ml})$ preincubated with or without amiloride for $30 \mathrm{~min}$ at $37^{\circ} \mathrm{C}$ were added to the bath. Kinin-releasing activity of kallikrein was measured with a Grass force-displacement transducer FT03C and Grass polygraph (Grass Instrument Co., Quincy, Mass.).

Rat uterus preparations (25). Virgin female SpragueDawley rats (150-200 g) were injected with $200 \mu \mathrm{g} / \mathrm{kg} 17 \beta$ estradiol ( $2 \mathrm{mg} / \mathrm{ml}$ in $95 \%$ ethanol) $20-24 \mathrm{~h}$ before sacrifice by cervical dislocation. Uterine horns were immediately removed and placed in de Jalon's solution aerated with $95 \% \mathrm{O}_{2} /$ $5 \% \mathrm{CO}_{2}$. Aliquots of rat urinary kallikrein $(0.1 \mathrm{EU} / \mathrm{ml})$ preincubated with or without amiloride for $30 \mathrm{~min}$ at $37^{\circ} \mathrm{C}$ were added to the isolated, estrogen-primed rat uterus in a $10-\mathrm{ml}$ tissue bath at $27^{\circ} \mathrm{C}$. Contractile responses of the tissue induced by kallikrein were recorded with the force-displacement transducer and polygraph.

\section{Spectrophotometric assay}

The initial velocity of $2-N$-thiobenzyl benzyloxycarbonylL-lysinate hydrolysis by rat urinary kallikrein was measured with a Cary 15 spectrophotometer (Varian Associates, Instrument Div., Palo Alto, Calif.) using the 0.1-absorbance slide wire. The reactions were carried out at $25^{\circ} \mathrm{C}$ by circulating water from a temperature-controlled bath (Haake Inc., Saddle Brook, N. J.) through thermospacers. Tubes containing either $2.7 \mathrm{ml}$ of $0.2 \mathrm{M}$ Tris- $\mathrm{HCl}$ buffer, $\mathrm{pH} 7.5$, and $0.05 \mathrm{ml}$ of $0.01 \mathrm{M} \mathrm{5,5'-dithiobis(2-nitrobenzoic} \mathrm{acid)} \mathrm{in} 0.1 \mathrm{M}$ sodium phosphate buffer, $\mathrm{pH} 7$, or containing rat urinary kallikrein $(0.1 \mathrm{EU} / \mathrm{ml})$ with and without amiloride in varying concentrations $(0.4 \mathrm{ml}$ total volume), were preincubated for $30 \mathrm{~min}$ at $25^{\circ} \mathrm{C}$. The substrate, thiobenzyl benzyloxycarbonyl-Llysinate, was added to the buffer-5, $5^{\prime}$-dithiobis(2-nitroben- 
zoic acid) mixture to make final substrate concentrations of from 12 to $80 \mu \mathrm{M}$ and a total volume of $2.95 \mathrm{ml}$. After $5 \mathrm{~min}$, the reactions were initiated by addition of either $0.05 \mathrm{ml}$ of enzyme alone or $0.05 \mathrm{ml}$ of enzyme-inhibitor solution, mixed, and then immediately transferred to the cuvette. Kallikrein activity was determined by measuring the linear production of 3-carboxy-4-nitrothiophenoxide ion (yellow anion) at 412 $\mathrm{nm}$ for $5 \mathrm{~min}$ and corrected for spontaneous hydrolysis in the reference cuvette containing the substrate, 5,5'-dithiobis(2nitrobenzoic acid) and amiloride, when indicated. Velocity is expressed as the molarity of product formed per minute using a molar extinction coefficient of $1.36 \times 10^{4}$ for 3 carboxy-4-nitrothiophenoxide ion (26). The reversibility of kallikrein inhibition by amiloride was determined by measuring $\mathrm{V}_{\max }\left(\mathrm{V}_{\max }=\right.$ the maximal velocity of thiobenzyl benzyloxycarbonyl-L-lysinate hydrolysis obtained from intercepts of Lineweaver-Burk plots as described above) at various kallikrein concentrations $(2-4 \mathrm{mEU} / 3-\mathrm{ml}$ reaction mixture) in the presence or absence of $(20 \mu \mathrm{M})$ amiloride. Irreversible inhibition can be distinguished from reversible noncompetitive inhibition by plotting $V_{\max }$ vs. the total amount of kallikrein in the assay, in the presence or absence of inhibitor. With reversible noncompetitive inhibition, the "plus inhibitor" curves will have smaller slopes than control, but pass through the origin. With irreversible inhibition, the plus inhibitor curves will have slopes similar to control, but will intersect the horizontal axis at a point equivalent to the amount of enzyme that is irreversibly inactivated.

\section{Renal cortical cell suspension preparations}

Renal cortical cell suspensions were prepared from Sprague-Dawley rats according to the procedures described by Chao and Margolius (17). Cell counts were performed with a hemocytometer and viability was determined using the trypan blue exclusion method (27). Intact viable renal cortical cells in suspension are capable of hydrolyzing TosArg-OMe and this activity was assayed as described previously (17).

\section{Amphibian enzyme extraction and assay}

Female Bufo marinus toads said to be of Mexican or Puerto Rican origin were obtained from Lemberger Co., Oshkosh, Wis., and kept upon moist pads at room temperature. The urinary bladders or skin were removed from doubly-pithed toads. Usually, four hemibladders were removed from two toads and rinsed several times with phosphate-buffered saline ( $\mathrm{pH}$ 7.4). Each hemibladder was placed in a petri dish, covered with phosphate-buffered saline and the surface was then scraped with a glass slide. The harvested cells were pooled and suspended in $5 \mathrm{ml}$ of the same buffer and filtered through three layers of gauze upon Nitex $(100-\mu \mathrm{m}$ pore size). These cell suspensions were homogenized twice in an Omni-mixer (Iowa Mfg. Co., Cedar Rapids, Iowa) at $4^{\circ} \mathrm{C}$ for $30 \mathrm{~s}$ each at top speed. The homogenates were treated with deoxycholate $(0.5 \%, \mathrm{wt} / \mathrm{vol})$ at $4^{\circ} \mathrm{C}$ for $30 \mathrm{~min}$ and then centrifuged at $20,000 \mathrm{~g}$ for $30 \mathrm{~min}$ at $4^{\circ} \mathrm{C}$. The supernate $(\sim 5 \mathrm{ml})$ was desalted by gel filtration through Sephadex G-25 (20). The filtrate was acid-treated by the procedure of Furtado (2) and kininase II activity inhibited with $200 \mu \mathrm{g} / \mathrm{ml} \mathrm{SQ20881.}$ Pieces of weighed ventral skin were minced, homogenized, and treated as the bladders. The protein concentration of these extracts was determined by the method of Lowry et al. (28). Tos-Arg-OMe esterase activity of these toad bladder or skin extracts was measured as described previously (17). The contractile responses of the isolated guinea pig ileum or estrogen-primed rat uterus were measured in response to toad skin or bladder extracts before or after the latter were incubated with heated dog plasma for $30-60 \mathrm{~min}$ at $37^{\circ} \mathrm{C}$. The Tos-Arg-OMe esterase activity of intact pieces of total bladder were measured in the following fashion. After toads were doubly-pithed, the thoracic cavity was opened, the vena cava was cut, and the ventricle was punctured and perfused with a standard frog Ringer's solution until the urinary hemibladder vessels appeared free of blood (usually $100-150 \mathrm{ml}$ of Ringer's solution). The hemibladders were then removed and rinsed in Ringer's solution and transferred to $50 \mathrm{ml}$ of Tris$\mathrm{HCl}$ buffer $0.2 \mathrm{M}, \mathrm{pH}$. Each hemibladder was then loosely mounted upon a wooden block with the mucosal surface upward and kept moist with the Tris- $\mathrm{HCl}$ buffer. 250.25 $\mathrm{cm}^{2}$ sections were punched out of each hemibladder with an Osborne arch punch (C. S. Osborne \& Co., Harrison, $\mathrm{N}$. J.) and individually placed in $1.5-\mathrm{ml}$ polypropylene tubes containing $0.03-0.04 \mathrm{ml}$ of the Tris- $\mathrm{HCl}$ buffer, $0.01 \mathrm{ml}$ of vehicle or vehicle plus amiloride (final concentrations as indicated) and allowed to stand at room temperature for 20 min. Tos-Arg-O $\left[{ }^{3} \mathrm{H}\right] \mathrm{Me}(0.047 \mu \mathrm{Ci}, 0.01 \mathrm{ml})$ was added, mixed, and incubated for $30 \mathrm{~min}$, the reaction was stopped and then $\left[{ }^{3} \mathrm{H}\right]$ methanol was measured as described above. Activity was measured in quadruplicate in vehicle-incubated pieces and in triplicate in amiloride-treated pieces.

Results are expressed as means $\pm 1 \mathrm{SE}$ where appropriate. Student's $t$ test for unpaired data was used to assess statistical significance.

\section{RESULTS}

Amiloride inhibition of mammalian kallikrein. Fig. 1 shows that the Tos-Arg-O $\left[{ }^{3} \mathrm{H}\right] \mathrm{Me}$ esterase activity of either rat or human urinary kallikrein was inhibited $50 \%$ by amiloride, $0.23 \mathrm{mM}$. In this assay system, all other diuretic drugs tested including: furosemide, hydrochlorothiazide, ethacrynic acid, spironolactone, and ouabain in concentrations ranging from $1 \mu \mathrm{M}$ to $1.7 \mathrm{mM}$ did not inhibit either rat or human urinary kallikrein activity to any degree. Triamterene, $1.7 \mathrm{mM}$, produced slight inhibition $(22.5 \pm 4.2 \%$, mean $\pm 1 \mathrm{SE}, n=6$ ) of rat urinary kallikrein activity. Fig. 1 also shows that the kallikrein-like esterase activity of isolated, viable renal cortical cells in suspension was also inhibited by amiloride with $50 \%$ inhibition seen at a drug concentration of $0.12 \mathrm{mM}$.

Inhibition of the activity of purified rat urinary kallikrein was also observed when its kinin-releasing activity was measured with a kinin radioimmunoassay. Fig. 2 shows that amiloride inhibits this activity of kallikrein with an $\mathrm{ID}_{50}$ of $\sim 85 \mu \mathrm{M}$. The slow contraction of the isolated guinea pig ileum seen when kallikrein was added to the tissue bath containing a source of kininogen was inhibited by preincubation of the enzyme with amiloride (Fig. 3). The contractile responses of the isolated rat uterus induced by rat urinary kallikrein alone were abolished by preincubating the enzyme with amiloride (Fig. 3). Amiloride never inhibited bradykinin-induced contractile responses of either the guinea pig ileum or rat uterus.

Fig. $4 a$ shows measurement of kallikrein activity upon the synthetic substrate, thiobenzyl benzyloxy- 


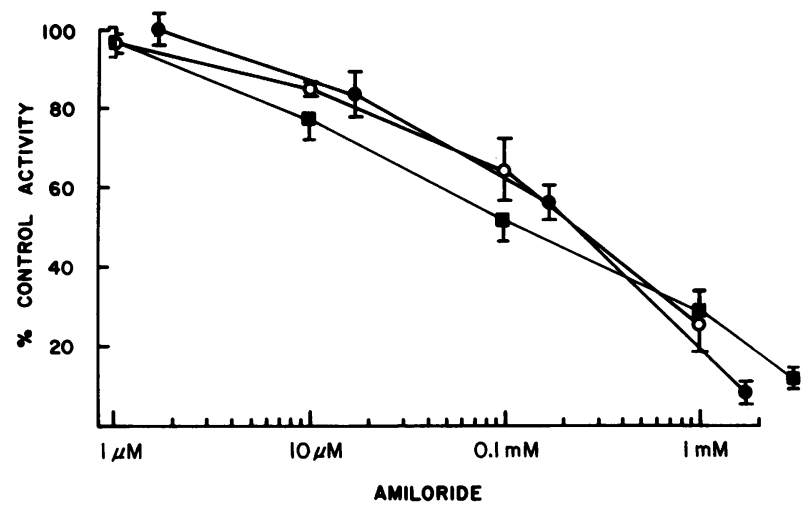

FIGURE 1 Inhibition of rat or human urinary kallikrein or of renal cortical cell suspension Tos-Arg-O $\left[{ }^{3} \mathrm{H}\right] \mathrm{Me}$ esterase activity by amiloride. $10 \mu \mathrm{l}(11 \mathrm{nM})$ of either rat (O) or human (O) urinary kallikrein $(20 \mathrm{mEU} / \mathrm{ml}, 1 \mathrm{EU}$ defined as in Methods), $10 \mu \mathrm{l}$ of water or water plus amiloride (final concentrations as indicated) and $30 \mu \mathrm{l}$ of $0.2 \mathrm{M}$ Tris- $\mathrm{HCl}$ buffer, $\mathrm{pH} 8$ were mixed and allowed to stand for $30 \mathrm{~min}$ at $25^{\circ} \mathrm{C}$. $20 \mu$ l of freshly prepared renal cortical cells $(\square)\left(5.0 \times 10^{6}\right.$ cells $/ \mathrm{ml}$ ) in phosphate-buffered saline containing $2 \mathrm{mM} \mathrm{Ca}^{2+}$, $20 \mu \mathrm{l}$ of $0.2 \mathrm{M}$ Tris- $\mathrm{HCl}$ buffer, $\mathrm{pH} 8$ and $10 \mu \mathrm{l}$ of water or water containing amiloride (final concentrations as indicated) were mixed and also allowed to stand for $30 \mathrm{~min}$ at $25^{\circ} \mathrm{C}$. Tos-Arg-O $\left[{ }^{3} \mathrm{H}\right] \mathrm{Me}\left(3.0 \times 10^{4} \mathrm{cpm}, 10 \mu \mathrm{l}\right)$ was added, mixed and allowed to incubate for $30 \mathrm{~min}$. The reaction was stopped and the $\left[{ }^{3} \mathrm{H}\right]$ methanol released was measured as described in Methods. Activity is expressed as the percent of control esterase activity in the absence of amiloride. Each value represents the mean $\pm 1 \mathrm{SE}$ of 12 experiments in duplicate for rat urinary kallikrein, six in duplicate with human urinary kallikrein and six in duplicate with separate rat renal cortical cell preparations.

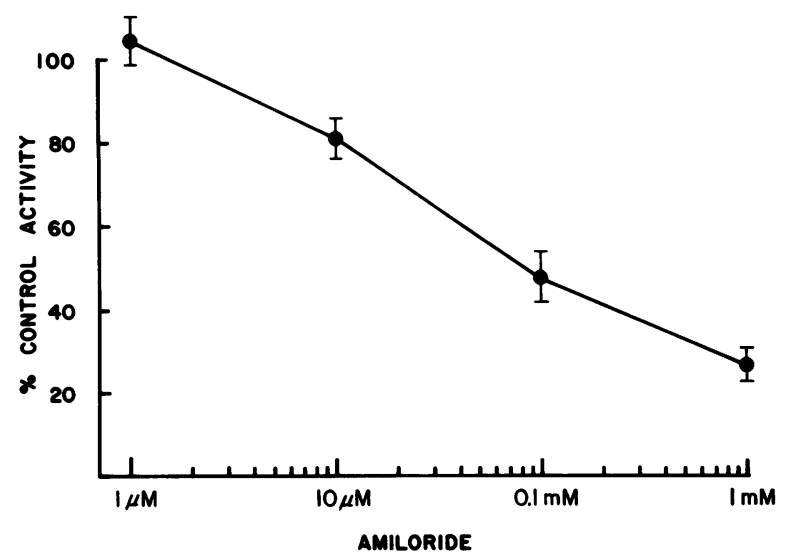

FIGURE 2 Inhibition of the kininogenase activity of rat urinary kallikrein by amiloride. Kinin-releasing activity was measured with a kinin radioimmunoassay. $50 \mu \mathrm{l}$ of rat urinary kallikrein $(40 \mathrm{mEU} / \mathrm{ml})$ and $50 \mu \mathrm{l}$ of water or water containing amiloride (final concentrations as indicated) were mixed and incubated at $37^{\circ} \mathrm{C}$ for $30 \mathrm{~min}$. The rest of the procedure is as described in Methods. Activity is expressed as the percent of control kinin generation in the absence of amiloride. Each value represents the mean $\pm 1 \mathrm{SE}$ of seven experiments in duplicate.
GUINEA PIG ILEUM
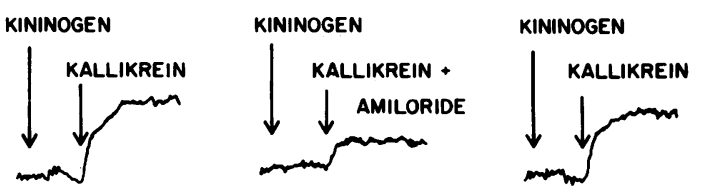

RAT UTERUS
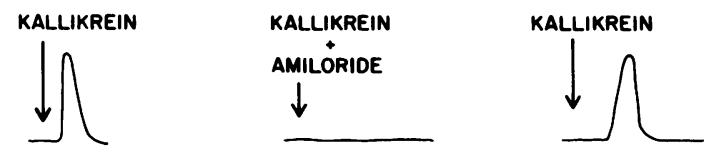

FIGURE 3 Bioassays of kallikrein in the absence and presence of amiloride. (Upper panel): The slow contractile response of the guinea pig ileum produced by kinin liberation from $0.1 \mathrm{ml}$ of heated dog plasma kininogen substrate incubated within the isolated tissue bath with $0.1 \mathrm{ml}$ of purified rat urinary kallikrein $(0.1 \mathrm{EU} / \mathrm{ml})$ is seen. The same quantity of enzyme was preincubated with $3 \mathrm{mM}$ amiloride for $30 \mathrm{~min}$ at $37^{\circ} \mathrm{C}$ and a $0.1-\mathrm{ml}$ aliquot was added to the bath. The response was inhibited by amiloride (bath concentration, $30 \mu \mathrm{M}$ ). After washing, the response returns. (Lower panel) The contractile response of the rat uterus was induced by $0.1 \mathrm{ml}$ of rat urinary kallikrein $(0.1 \mathrm{EU} / \mathrm{ml})$. The same quantity of enzyme was preincubated with $3 \mathrm{mM}$ amiloride for $30 \mathrm{~min}$ at $37^{\circ} \mathrm{C}$ and a 0.1 $\mathrm{ml}$ aliquot was added to the bath. The response was inhibited by amiloride (bath concentration, $30 \mu \mathrm{M}$ ). After washing, the response returns.

carbonyl-L-lysinate at $\mathrm{pH}$ 7.5. In this typical Lineweaver-Burk plot, the rate of substrate hydrolysis varied as a function of substrate concentration according to the Michaelis-Menten model. Amiloride, 6.67-33 $\mu \mathrm{M}$, did not affect $K_{\mathrm{m}}$ (calculated to be 0.125 $\mathrm{mM}$ when the line was fitted to the experimental points by linear regression analysis, $r=0.99$ ) but increased $1 / V_{\max }$ indicating a noncompetitive inhibition of the enzyme. Secondary plots of the intercepts (not shown) or slopes (Fig. $4 b$ ) vs. amiloride concentration were also linear, and support the interpretation of noncompetitive inhibition of kallikrein by amiloride. The calculated $K_{\mathbf{i}}$ for kallikrein inhibition by amiloride (using linear regression analysis, $r=0.98$ ) was 26 $\mu \mathrm{M}$. Data obtained at $\mathrm{pH} 8$ also indicated noncompetitive inhibition with a $K_{\mathrm{i}}$ of $25 \mu \mathrm{M}$ and the lower $K_{\mathrm{m}}$ $(67 \mu \mathrm{M})$ expected as the enzyme approaches its $\mathrm{pH}$ optimum (8.5-9.0) (20). The experiments in Fig. $4 c$ show that the slope of $V_{\max } v$ s. various concentrations of enzyme is smaller in the presence of amiloride but the intercept of this plot is at the origin, indicating reversible inhibition.

Amphibian kallikrein-like activity. Toad bladder or skin extracts (12 preparations at various times of the year) contained from 0.03 to $0.09 \mathrm{EU} / \mathrm{mg}$ protein 

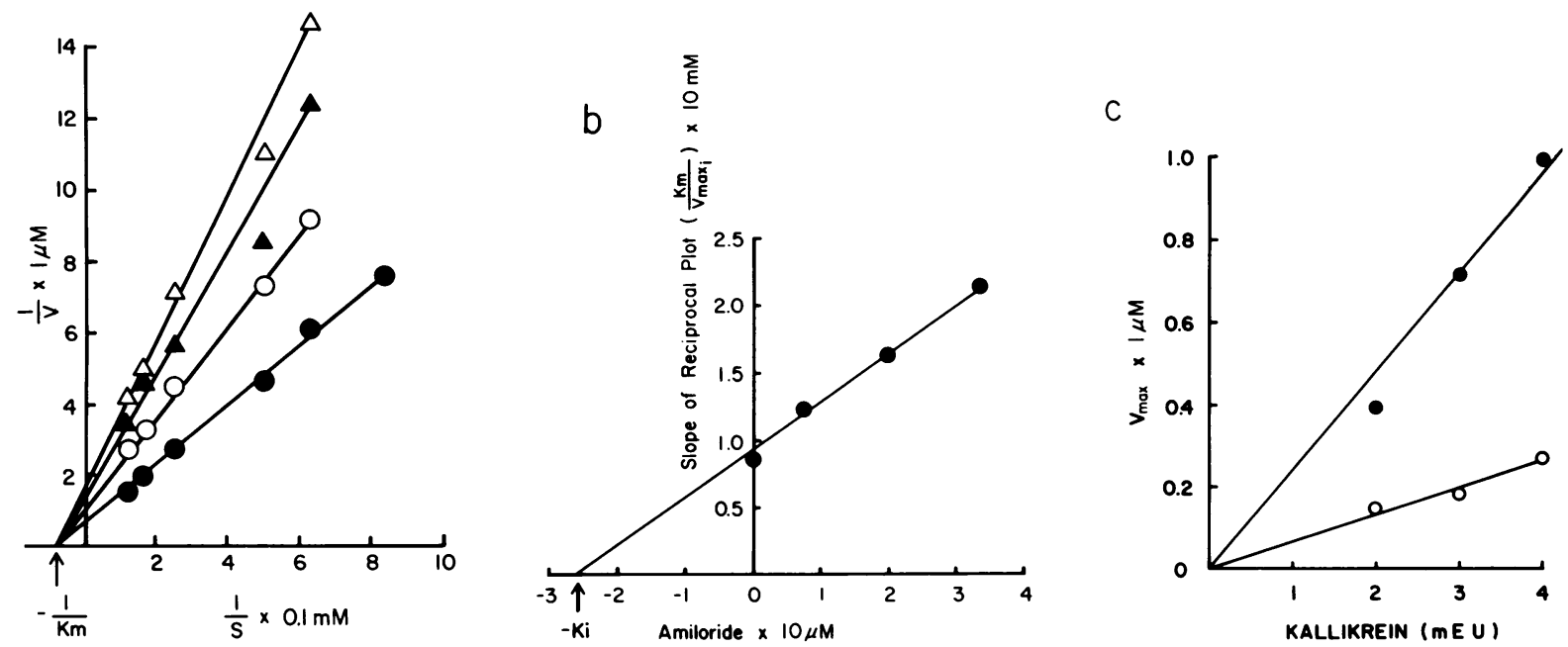

FIgURE 4(a) Lineweaver-Burk plot of initial reaction velocity, V, vs. substrate concentrations, $\mathrm{S}$, in the absence $(\bigcirc)$ and in the presence of amiloride $[6.7 \mu \mathrm{M},(\bigcirc) ; 20 \mu \mathrm{M},(\Delta) ; 33 \mu \mathrm{M},(\Delta)] .(b)$ Secondary plot of the slopes from the primary Lineweaver-Burk plot vs. amiloride concentration. (c) Plot of $\mathrm{V}_{\max }$ vs. kallikrein concentration. (O) control; (O) $20 \mu \mathrm{M}$ amiloride. Velocities are expressed as the molar concentration of 3-carboxy-4-nitrothiophenoxide ion formed in the reaction mixture over a 1-min period after addition of kallikrein.

against Tos-Arg-O $\left[{ }^{3} \mathrm{H}\right] \mathrm{Me}$ using human urinary kallikrein as the standard. The $\mathrm{pH}$ profile of this esterase activity from either urinary bladder or skin followed a Gaussian distribution with an optimum of 9.

A typical illustration of the biological activity of toad skin extract is shown in Fig. 5. The guinea pig ileum responded to the extract plus kininogen from heated dog plasma with characteristic slow contraction. This response was prevented by preincubation with carboxypeptidase B. When carboxypeptidase B was placed in the tissue bath $(2-3 \mathrm{U} / \mathrm{ml})$, the response was also abolished.

Table I shows that this kallikrein-like alkaline

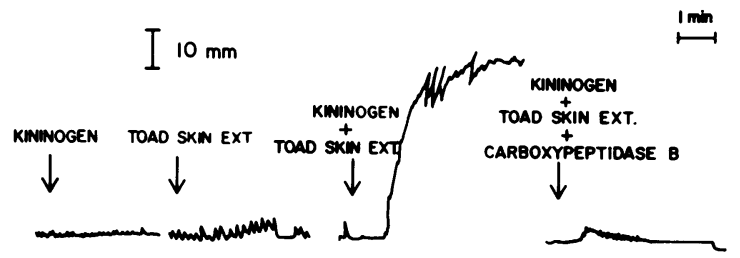

FIGURE 5 Bioassay of kinin-releasing activity of toad skin extract. The isolated guinea pig ileum was bathed in $10 \mathrm{ml}$ of Tyrode's solution. Neither heated dog plasma (kininogen) nor the toad skin acid-treated extract alone produced contractile responses. $0.1 \mathrm{ml}$ of substrate was incubated with $0.1 \mathrm{ml}$ of toad skin extract $(0.1 \mathrm{EU} / \mathrm{ml}, 0.05 \mathrm{EU} / \mathrm{mg}$ protein) in Tris buffer, $0.2 \mathrm{M} \mathrm{pH} 8(0.6 \mathrm{ml}$ total volume $)$ for $30 \mathrm{~min}$ at $37^{\circ} \mathrm{C}$. After the reaction was stopped by boiling for $5 \mathrm{~min}$ and the tubes cooled, a $0.05-\mathrm{ml}$ aliquot produced a contraction equivalent to that seen with $10 \mathrm{ng}$ of synthetic bradykinin. Addition of $21.5 \mathrm{U}$ of carboxypeptidase B after cooling abolished the contractile response. esterase activity was inhibited by several inhibitors of mammalian glandular kallikrein. Aprotinin, a potent inhibitor of mammalian glandular kallikrein $(19,29)$, inhibited this esterase activity $\left(\mathrm{ID}_{50}=28 \mu \mathrm{M}\right)$. Phenylmethylsulfonyl fluoride, a specific serine proteinase

TABLE I

Inhibition of Toad Bladder Tos-Arg-O $\left[{ }^{3} \mathrm{H}\right] \mathrm{Me}$ Esterase Activity

\begin{tabular}{lcccr}
\hline & \multicolumn{4}{c}{ Inhibition, \% } \\
\cline { 2 - 5 } \multicolumn{1}{c}{ Inhibitor } & $39 \mu \mathrm{M}$ & \multicolumn{2}{c}{$3.9 \mu \mathrm{M}$} & $0.39 \mu \mathrm{M}$ \\
\hline Aprotinin & 56 & & 17 & 12 \\
& & & & \\
& $1.7 \mathrm{mM}$ & $0.17 \mathrm{mM}$ & $17.0 \mu \mathrm{M}$ & $1.7 \mu \mathrm{M}$ \\
\cline { 2 - 5 } & & & & \\
Phenylmethylsulfonyl & 90 & 32 & 22 & 2 \\
$\quad$ fluoride & 98 & 76 & 24 & 7 \\
Benzamidine & 100 & 99 & 96 & 63 \\
Pentamidine & 100 & 89 & 46 & 30 \\
IRT-36 & 100 & 100 & 93 & 55 \\
IRT-63 & 100 & 78 & 20 & 2 \\
Amiloride & & &
\end{tabular}

$10 \mu \mathrm{l}$ of the toad bladder extract $(20 \mathrm{mEU} / \mathrm{ml}), 10 \mu \mathrm{l}$ of vehicle or vehicle plus inhibitor (final concentrations as shown) and $30 \mu \mathrm{l}$ of $0.2 \mathrm{M}$ Tris-HCl buffer, $\mathrm{pH} 8$, were mixed and allowed to stand for $30 \mathrm{~min}$. Tos-Arg-O $\left[{ }^{3} \mathrm{H}\right] \mathrm{Me}$ esterase activity was measured as described in Fig. 1 and Methods. Activity is expressed as percent inhibition compared to controls. Each value represents the average of three experiments in duplicate. Identical inhibitory patterns exist for toad skin extract alkaline esterase activity. 
inhibitor (29), inhibits bladder esterase activity at an $\mathrm{ID}_{50}$ of $0.35 \mathrm{mM}$. Benzamidine and pentamidine are strong inhibitors of trypsin and kallikrein, and IRT-36 and IRT-63 are more potent inhibitors of kallikrein than other serine proteinases $(30)$. The $\mathrm{ID}_{50}$ of benzamidine, pentamidine, IRT-36 and IRT-63 were 56, 1, 20, and $1 \mu \mathrm{M}$, respectively. Trypsin inhibitors from lima bean or ovomucoid do not inhibit purified mammalian glandular kallikrein (19) and soybean trypsin inhibitor does so, weakly; they did not inhibit toad bladder extract esterase activity in concentrations up to $1.7 \mathrm{mg} / \mathrm{ml}$. Finally, the diuretic drug amiloride also inhibited this extract alkaline esterase activity $\left(\mathrm{ID}_{50}=50 \mu \mathrm{M}\right)$. All other diuretics tested including: furosemide, hydrochlorothiazide, ethacrynic acid, spironolactone, and ouabain, in concentrations ranging from $1 \mu \mathrm{M}$ to 1.7 $\mathrm{mM}$, did not inhibit this activity to any degree.

Tos-Arg-O $\left[{ }^{3} \mathrm{H}\right] \mathrm{Me}$ esterase activity of toad bladder pieces was measured in the absence and presence of amiloride, $1 \mathrm{nM}-1 \mathrm{mM}$. Fig. 6 shows that significant inhibition was detected at an amiloride concentration of $10 \mathrm{nM}$ although the $\mathrm{ID}_{50}$ was $\sim 0.1 \mathrm{mM}$.

\section{DISCUSSION}

The results show that amiloride can inhibit kallikrein and kallikrein-like enzyme activity. The inhibition appears to be of a noncompetitive and reversible type. The inhibitory effects of amiloride can be detected with a variety of assay systems and can be observed using a purified homogenous rat urinary kallikrein, a partially purified human urinary kallikrein, or kallikrein-like activities upon the surface of rat renal cortical

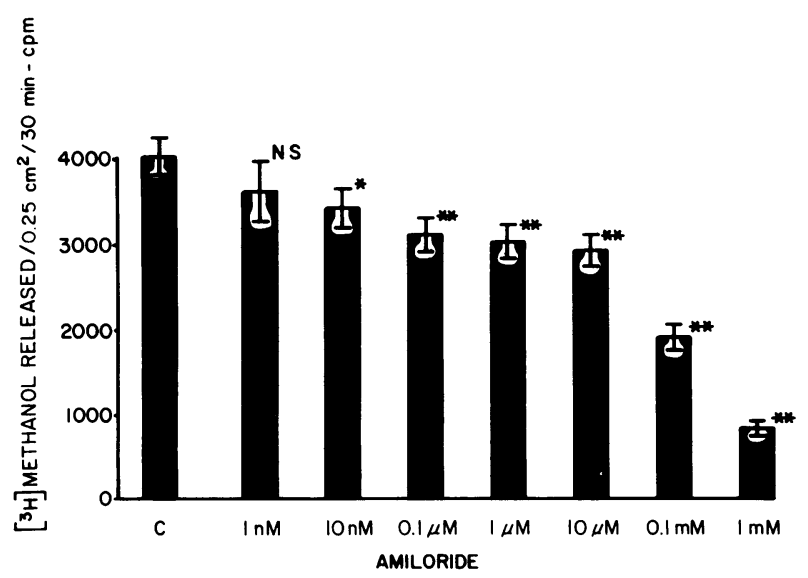

Figure 6 Tos-Arg-O $\left[{ }^{3} \mathrm{H}\right]$ Me esterase activity of toad bladder pieces in the absence $(C)$ or presence of amiloride. Each bar represents the mean $\pm 1 \mathrm{SE}$ of the Tos-Arg-O $\left[{ }^{3} \mathrm{H}\right] \mathrm{Me}$ esterase activity (expressed as counts per minute of $\left[{ }^{3} \mathrm{H}\right]$ methanol released $/ 0.25 \mathrm{~cm}^{2} /$ per $30 \mathrm{~min}$ ) of no less than 45 separate pieces from 15 to 20 hemibladders. NS-not significantly different from control. *, ${ }^{* *}$, differ from control with $P<0.05$ or 0.001 , respectively. cells in suspension, in toad bladder pieces, or in extracts of toad bladder or skin. The concentration of amiloride required to inhibit enzyme activity $50 \%$ ranges from 85 to $230 \mu \mathrm{M}$ depending upon substrate, enzyme preparation, or assay system. A minimal, but significant effect was detected at $10 \mathrm{nM}$ amiloride using toad bladder pieces. Of the other diuretic agents tested, using the most convenient assay system (TosArg-OMe esterase activity) and the most pure enzyme preparation (rat urinary kallikrein B purified to homogeneity) (19), only triamterene produced any detectable inhibition, and this was minimal. Furosemide, hydrochlorothiazide, ethacrynic acid, spironolactone, and ouabain were without inhibitory effects over a broad range of concentrations.

Amiloride is a substituted pyrazine carboxamide developed as a result of a search for a nonsteroidal natriuretic, antikaluretic agent (31). It has become useful as a probe of membrane ion transport since its effects upon short-circuit current, a reflection of active sodium transport, were first demonstrated in amphibian tissues $(32,33)$. It has been shown subsequently that amiloride acts upon susceptible amphibian (bladder, colon, skin) and mammalian (distal nephron, colon, salivary duct) sites to rapidly and reversibly inhibit permeability to sodium at the mucosal surface or apical cell borders (34). The local concentrations required to reduce permeability to sodium ions $50 \%$ vary widely, and range from $20 \mathrm{nM}$ in frog skin bathed in low sodium (35) to $0.1 \mathrm{mM}$ or higher in micropunctured, perfused rat distal tubules (36). Thus, the concentrations of this drug which reduce membrane sodium permeability are similar to those which inhibit kallikrein or kallikrein-like enzyme activity to an equivalent degree.

Although it must be emphasized that the present data do not indicate that mammalian glandular kallikrein plays any role in the mechanism of action of amiloride, there are reasons to support further investigation of this notion. First, the tissues in which amiloride is known to act are also those containing kallikrein or a kallikrein-like activity, e.g., kidney, salivary glands, sweat glands, colon and now, amphibian bladder and skin. Second, recent biochemical (16), histochemical $(14,15)$, and physiologic (37) evidence has suggested that the enzyme is bound within apical plasma membranes of the distal nephron or salivary ducts and gains access to tubular fluid from these sites where amiloride is known to act. Third, the studies of Crocker and Willavoys (1) have shown that low concentrations of bradykinin ( $10 \mathrm{pM})$ can increase $\mathrm{Na}^{+}$and water transfer from mucosal to serosal surface of the rat jejunum when basal transfer rates are low. Finally, our own preliminary studies (38) have shown that inhibitors of mammalian glandular kallikrein reduce short-circuit current in the isolated toad 
bladder. On the other hand, no published studies have examined comprehensively the effects of kallikreinkinin system components upon electrolyte and water transport in tissues where these components reside. Thus, studies of the direct effects of kinin peptides, glandular kallikrein substrates, and inhibitors or antibodies to the enzyme and peptides, upon ion and water transport in the distal nephron or amphibian bladder must be carried out to determine if the system has a role in ion transport or the mechanism of action of amiloride.

In summary, the results of the present study prove that a drug known to inhibit $\mathrm{Na}^{+}$reabsorption reversibly at specific sites of glandular kallikrein localization can, in similar concentrations, noncompetitively and reversibly inhibit kallikrein or an amphibian kallikrein-like activity. The facts suggest that further investigation of the actions of components of the glandular kallikrein-kinin system upon ion and water transport at pertinent mammalian and amphibian sites would be of interest, as would be studies of relations between the effects of amiloride and its analogues upon kallikrein, and renal electrolyte and water transport.

\section{ACKNOWLEDGMENTS}

The authors are grateful to Marie Truesdell and Nita Pike for typing the manuscript.

Support for this work was provided by research grants GM 20387 and HL 17705 of the National Institutes of Health, Bethesda, Md.

\section{REFERENCES}

1. Crocker, A. D., and S. P. Willavoys. 1975. Effect of bradykinin on transepithelial transfer of sodium and water in vitro. J. Physiol. (Lond.). 253: 401-410.

2. Furtado, M. R. F. 1971. Inhibition of the permeability response to vasopressin and oxytocin in the toad bladder: effects of bradykinin, kallidin, eledoisin and physalaemin. J. Membr. Biol. 4: 165-178.

3. Margolius, H. S., D. Horwitz, R. G. Geller, R. W., Alexander, Jr., J. R. Gill, Jr., J. J. Pisano, and H. R. Keiser. 1974. Urinary kallikrein excretion in normal man. Relationships to sodium intake and sodium-retaining steroids. Circ. Res. 35: 812-819.

4. Horwitz, D., H. S. Margolius, and H. R. Keiser. 1978. Effects of dietary potassium and race on urinary excretion of kallikrein. J. Clin. Endocrinol. Metab. 47: 296-299.

5. Vinci, J. M., R. M. Zusman, J. L. Izzo, Jr., R. E. Bowden, D. Horwitz, J. J. Pisano, and H. R. Keiser. 1979. Human urinary and plasma kinins. Relationship to sodium-retaining steroids and plasma renin activity. Circ. Res. 44: 228-237.

6. Nasjletti, A., J. C. McGiff, and J. Colina-Chourio. 1978. Interrelations of the renal kallikrein-kinin system and renal prostaglandins in the conscious rat. Circ. Res. 43: 799-807.

7. Geller, R. G., H. S. Margolius, J. J. Pisano, and H. R. Keiser. 1972. Effects of mineralocorticoids, altered sodium intake and adrenalectomy on urinary kallikrein in rats. Circ. Res. 31: 857-861.

8. Mimran, A., G. Baudin, D. Casellas, and D. Soulas. 1977.
Urinary kallikrein and changes in endogenous aldosterone in the rat. Eur. J. Clin. Invest. 7: 497-502.

9. Kaizu, T., and H. S. Margolius. 1975. Studies on rat renal cortical cell kallikrein. I. Separation and measurement. Biochim. Biophys. Acta. 411: 305-315.

10. Margolius, H. S., D. Horwitz, J. J. Pisano, and H. R. Keiser. 1974. Urinary kallikrein excretion in hypertensive man. Relationship to sodium intake and sodiumretaining steroids. Circ. Res. 35: 820-825.

11. Lechi, A., G. Covi, C. Lechi, F. Mantero, and L. A. Scuro. 1976. Urinary kallikrein excretion in Bartter's syndrome. J. Clin. Endocrinol. Metab. 43: 1175-1178.

12. Halushka, P. V., H. Wohltmann, P. J. Privitera, G. Hurwitz, and H. S. Margolius. 1977. Bartter's syndrome: Urinary prostaglandin E-like material and kallikrein: indomethacin effects. Ann. Intern. Med. 87: 281-286.

13. Vinci, J. M., J. R. Gill, Jr., R. E. Bowden, J. J. Pisano, J. L. Izzo, Jr., N. Radfar, A. A. Taylor, R. M. Zusman, F. C. Bartter, and H. R. Keiser. 1978. The kallikrein-kinin system in Bartter's syndrome and its response to prostaglandin synthetase inhibitors. J. Clin. Invest. 61: 16711682.

14. Ørstavik, T. B., K. Nustad, P. Brandtzaeg, and J. V. Pierce. 1978. Cellular origin of urinary kallikreins. $J$. Histochem. Cytochem. 24: 1037-1039.

15. Simson, J. A. V., S. S. Spicer, J. Chao, L. Grimm, and H. S. Margolius. 1979. Kallikrein localization in rodent salivary glands and kidney with the immunoglobulin-enzyme bridge technique. J. Histochem. Cytochem. 27: 15671576.

16. Ward, P. E., C. Gedney, R. M. Dowben, and E. G. Erdös. 1975. Isolation of membrane-bound renal kallikrein and kininase. Biochem. J. 151: 755-758.

17. Chao, J., and H. S. Margolius. 1979. Studies on rat renal cortical cell kallikrein. II. Identification of kallikrein as an ecto-enzyme. Biochim. Biophys. Acta. 570: 330-340.

18. Stoner, L. C. 1979. Studies with amiloride on isolated distal nephron segments. In Amiloride and Epithelial Sodium Transport. A. W. Cuthbert, G. M. Fanelli, Jr., and A. Scriabine, editors. Urban and Schwarzenberg, Baltimore. 51-60.

19. Chao, J., and H. S. Margolius. 1979. Isozvmes of rat urinary kallikrein. Biochem. Pharmacol. 28: 2071-2079.

20. Beaven, V. H., J. V. Pierce, and J. J. Pisano. 1971. Sensitive isotopic procedure for the assay of esterase activity: measurement of human urinary kallikrein. Clin. Chim. Acta. 32: 67-73.

21. Pierce, J. V. 1970. Purification of mammalian kallikreins, kininogens and kinins. In Handbook of Experimental Pharmacology: Bradykinin, Kallidin, and Kallikrein. E. G. Erdös, editor. Springer-Verlag, Berlin. 25: 21-51.

22. Shimamoto, K., S. Tanaka, T. Nakao, T. Ando, Y. Nakahashi, M. Sakuma, and M. Miyahara. 1979. Measurement of urinary kallikrein activity by kinin radioimmunoassay. Jpn. Circ. J. 43: 147-152.

23. Shimamoto, K., T. Ando, T. Nakao, S. Tanaka, M. Saduma, and M. Miyahara. 1978. A sensitive radioimmunoassay method for urinary kinins in man. J. Lab. Clin. Med. 91: $721-728$.

24. Webster, M. E., and E. S. Prado. 1970. Glandular kallikreins from horse and human urine and hog pancreas. Methods Enzymol. 19: 681-687.

25. Nustad, K. 1970. The relationship between kidney and urinary kininogenase. Br. J. Pharmacol. 39: 73-86.

26. Green, G. D. J., and E. Shaw. 1979. Thiobenzyl benzyloxycarbonyl-L-lysinate, substrate for a sensitive colorimetric assay for trypsin-like enzymes. Anal. Biochem. 93: $223-226$. 
27. Hoskins, J. M., G. C. Meynell, and F. K. Saunders. 1956. A comparison of methods for estimating the viable count of a suspension of tumor cells. Exp. Cell Res. 11: 297-305.

28. Lowry, O. H., N. J. Rosebrough, A. L. Farr, and J. R. Randall. 1951. Protein measurement with the folin phenol reagent. J. Biol. Chem. 193: 265-275.

29. Vogel, R., and E. Werle. 1970. Kallikrein inhibitors. In Handbook of Experimental Pharmacology: Bradykinin, Kallidin and Kallikrein. E. G. Erdös, editor. SpringerVerlag, Berlin. 25: 213-239.

30. Tidwell, R. R., L. L. Fox, and J. D. Geratz. 1976. Aromatic tris-amidines. A new class of highly active inhibitors of trypsin-like proteases. Biochim. Biophys. Acta. 445: 729738.

31. Cragoe, E. J., Jr. 1979. Structure-activity relationships in the amiloride series. In Amiloride and Epithelial Sodium Transport. A. W. Cuthbert, G. M. Fanelli, Jr., and A. Scriabine, editors. Urban and Schwarzenberg, Baltimore. 1-20.

32. Eigler, J., J. Ketter, and E. Renner. 1967. Wirkungscharacteristik eines neuen acylguanadins-amiloride- $\mathrm{HCl}$ an der isolierten haut von amphibien. Klin. Wochenschr. 43: 737-738.

33. Bentley, P. J. 1968. Amiloride: a potent inhibitor of sodium transport across the toad bladder. J. Physiol. (Lond.). 195: 317-330.

34. Bentley, P. J. 1979. The comparative pharmacology of amiloride. In Amiloride and Epithelial Sodium Transport. A. W. Cuthbert, G. M. Fanelli, Jr., and A. Scriabine, editors. Urban and Schwarzenberg, Baltimore. 35-40.

35. Cuthbert, A. W. 1973. An upper limit to the number of sodium channels in frog skin epithelium. J. Physiol. (Lond.). 228: 681-692.

36. Duarte, C. G., F. Chomety, and G. Giebisch. 1971. Effect of amiloride, ouabain, and furosemide on distal tubular function in the rat. Am. J. Physiol. 221: 632-640.

37. Scicli, A. G., O. A. Carretero, A. Hampton, P. Cortes, and N. B. Oza. 1976. Site of kininogenase secretion in the dog nephron. Am. J. Physiol. 230: 533-536.

38. Orce, G. G., G. A. Castillo, and H. S. Margolius. 1979. The effects of aprotinin on short circuit current in the toad bladder. Fed. Proc. 38: 750. (Abstr.) 